\title{
PENGHITUNGAN STANDAR WAKTU OPERASI DAN OUTPUT PRODUKSI SEBAGAI DASAR EVALUASI PRODUKTIVITAS KERJA
}

\author{
Aisyah Larasati \\ Agus Hery Supadmi Irianty \\ Hapsari Kusumawardhani \\ Jurusan Teknologi Industri Fakultas Teknik Universitas Negeri Malang \\ e-mail: aisyah.larasati.nàum.ac.id
}

\begin{abstract}
In Fashion Design study program, making a t-shirt is one of courses offered by the department. Arranging of an operation process chart of making a t-shirt enhances the students* knowledge and understanding on the procedure of making a t-shit properly. In addition, the operation process chart may also be used to evaluate the student pace in order to help them adapting to the industry more rapidly. Data was collected through an observation using a stop watch method. This research is completed by direct observation with stop watch method. This study used a simple random sample. Ten students were chosen as the samples. Each student repeated the process of making a t-shirt for three times. The results show that the standard time for a student to complete making three units of t-shirt is approximately 286 minutes, and the standard output is 0.629 uniVhour.
\end{abstract}

\begin{abstract}
Abstrak: Pembuatan t-shirt merupakan salah satu pembelajaran yang diberikan kepada mahasiswa Tata Busana. Penyusunan peta proses operasi pembuatan $t$-shirt anak dapat membantu mahasiswa untuk mengetahui dan memahami alur pembuatan t-shirt anak secara tepat. Selain itu, pembuatan peta proses dapat juga digunakan sebagai alat evaluasi kecepatan kerja mahasiswa sehingga dapat lebih cepat beradaptasi dengan kecepatan produksi yang umumnya diterapkan di industri $t$-shirt. Data didapatkan dengan metode observasi menggunakan stop watch. Sampel dipilih secara acak. Sepuluh orang mahasiswa terpilih sebagai sampel. Setiap mahasiswa mengulang pembuatan t-shirt anak sebanyak tiga kali. Hasil yang didapat menunjukkan bahwa waktu standar yang dibutuhkan mahasiswa untuk menyelesaikan tiga unit t-shirl anak adalah kurang lebih 286 menit dan output standar yang diperoleh adalah 0,629 unit per jam.
\end{abstract}

Kata kunci: waktu standar, output standar, watch time study

Globalisasi industri yang terjadi pada setiap jenis industri, termasuk diantaranya terjadi pada industri di bidang busana, telah memaksa setiap pelaku usaha untuk meningkatkan daya saing perusahaan yang dikelola. Salah satu langkah yang dapat ditempuh untuk meningkatkan daya saing suatu industri adalah dengan meningkatkan produktivitas kerja perusahaan. Peningkatan produktivitas kerja, khususnya di lantai produksi, merupakan salah satu kunci meningkatkan daya saing di industri yang dapat ditempuh dengan cara melakukan pengawasan kerja operator produksi berdasarkan prosedur dan instruksi kerja yang telah ditetapkan sesuai dengan tugas dan tanggung jawab masing-masing operator. Salah satu bentuk prosedur kerja yang dapat dengan mudah dibaca adalah peta proses operasi (Operation Process Chart) (Dilworth, 2005).

Peta proses operasi sangat membantu operator untuk memahami prosedur kerja dan target produksi secara lebih terperinci. Adanya waktu standar kerja pada peta proses operasi dapat digunakan sebagai alat evaluasi kecepatan kerja operator pada setiap elemen kegiatan serta 
sebagai landasan untuk menentukan jumlah output standar (Mundel \& Danner, 1994). Selain itu. peta proses operasi juga mampu menyampaikan informasi yang berkaitan dengan: (I) informasi benda kerja berupa gambar kerja, jumlah, spesifikasi material dan dimensi ukuran pekerjaan; (2) macam proses kerja yang dilakukan, jenis dan spesifikasi mesin, peralatan produksi, dan alat bantu produksi lainnya; dan (3) informasi kapasitas mesin atau kapasitas alat kerja lain yang dipergunakan (Rastogi, 2010). Pemanfaatan peta proses operasi dalam perbaikan metode kerja dapat membantu suatu industri untuk meminimumkan aktivitas material handling yang tidak perlu, mengurangi jarak perpindahan benda dan tenaga kerja, meminimumkan waktu delay, serta menunjukkan aktivitas inspeksi yang berlebihan.

Waktu standar menggambarkan waktu yang dibutukkan untuk menyelesaikan proses operasi produksi, sedangkan output standar menggambarkan jumlah produk yang dihasilkan per satuan waktu. Kedua hal tersebut merupakan indikator produktivitas kerja yang cukup akurat. Oleh sebab itu, dalam kegiatan produksi perlu dilakukan pengukuran waktu standar dalam menyelesaikan suatu proses operasi sehingga dapat diketahui jumlah output standar yang ingin dicapai oleh perusahaan (Niebel 1993). Hasil penetapan waktu standar dan output standar merupakan tolok ukur yang akan digunakan untuk menilai performansi dari operator produksi. Hasil penilaian ini akan memberikan gambaran pemahaman prosedur kerja oleh operator serta kemampuan operator dalam menyelesaikan pekerjaannya (Niebel \& Freivalds, 2003).

Pada program studi Tata Busana, pembuatan t-shirt anak merupakan salah satu bagian dari mata kuliah pembuatan busana industri. Oleh sebab itu, dalam proses belajar mengajar mata kuliah busana industri khususnya pembuatan tshirt anak, pembuatan peta proses operasi pembuatan $t$-shirt anak diperlukan untuk membantu mahasiswa mengetahui dan memahami prosedur kerja pembuatan -shirt anak yang benar serta kecepatan kerja normal agar nantinya dapat menyesuaikan diri dengan cepat saat terjun ke dunia industri busana. Penyusunan peta proses operasi pembuatan t-shirt anak dilakukan melalui dua tahap: Pertama, dilakukan pengamatan terhadap prosedur kerja pembuatan t-shirt anak sehingga dapat diketahui elemen-elemen kegiatan yang ada pada setiap tahapan proses produksi. Kedua, dilakukan pengukuran waktu kerja pada setiap elemen kegiatan yang telah diidentifikasikan sehingga dapat diketahui waktu standar pada setiap elemen kegiatan.

Penelitian ini dilakukan dengan tujuan menentukan waktu standar dan output standar -kerja mahasiswa dalam pembuatan t-shirt anak. Selain itu, penelitian ini juga bertujuan untuk menyusun peta proses operasi pembuatan t-shirt anak sehingga dapat digunakan sebagai bahan pertimbangan dalam menentukan target produksi mahasiswa saat melakukan pembuatan t-shirt anak pada perkuliahan teknik pembuatan busana industri. Manfaat lain yang diharapkan dari hasil penelitian ini adalah sebagai referensi pelengkap yang dapat digunakan sebagai alat bantu dosen dalam mengevaluasi kemampuan dan kecepatan mahasiswa membuat $t$-shirt anak.

\section{METODE}

Penelitian ini dilakukan dengan menggunakan pendekatan pengukuran waktu kerja dengan jam henti (Stop Watch Time Study). Pengukuran waktu kerja dengan jam henti sangat sesuai untuk diaplikasikan pada pekerjaanpekerjaan yang berlangsung singkat dan berulang-ulang (Whitmore, 1980). Dari hasil pengukuran akan diperoleh waktu standar untuk menyelesaikan suatu siklus pekerjaan. Waktu standar ini akan dipergunakan sebagai standar penyelesaian pekerjaan yang sama. Secara garis besar langkah-langkah untuk pelaksanaan pengukuran waktu kerja dengan jam henti dapat diuraikan sebagai berikut: (1) Mendefinisikan pekerjaan yang akan diteliti dan diukur waktunya serta memberitahukan tujuan pengukuran kepada operator yang diamati; (2) Mencatat semua informasi yang berkaitan erat dengan penyelesaian pekerjaan seperti lay out, spesifikasi mesin atau peralatan kerja lain yang digunakan; 
(3)Membagi operasi kerja dalam elemen-elemen kerja sedetail-detailnya tetapi masih dalam batasbatas kemudahan untuk pengukuran waktunya; (4) Menganati, mengukur dan mencatat waktu yang dibutuhkan oleh operator untuk menyelesaikan elemen kerja tersebut; (5) Menetapkan jumlah siklus kerja yang harus diukur dan dicatat; (6) Menetapkan tingkat performansi operator; (7) Menetapkan kelong-garan waktu yang dibutuhkan; (8) Menghitung waktu standar dan jumlah output standard.

\section{Prosedur Eksperimen}

Penelitian ini menggunakan rancangan desain eksperimen acak sempurna dengan jumlah sampel sebanyak 10 orang dan replikasi sebanyak 3 kali. Eksperimen yang dilakukan berupa eksperimen pembuatan $t$-shirt anak yang dilakukan oleh mahasiswa. Penelitian dilakukan di Laboratorium Industri Program Studi Tata Busana.

Proses pengumpulan data dilakukan dengan mengamati proses pembuatan t-shirt anak sehingga dapat diketahui elemen-elemen kegiatan yang dilakukan pada setiap tahapan proses produksi serta pencatatan waktu yang dibutuhkan pada setiap elemen kegiatan tersebut. Hasil pengamatan akan dipakai sebagai acuan pembuatan peta proses operasi pembuatan t-shirt anak, sedangkan hasil pencatatan waktu yang diperoleh akan digunakan dalam proses penghitungan waktu standar.

Sebelum dilakukan perhitungan waktu standar, hasil pencatatan waktu yang diperoleh akan diuji keseragamannya dengan tujuan memastikan bahwa data yang digunakan berasal dari populasi yang sama. Setelah data terbukti seragam, maka dilanjutkan dengan uji kecukupan data dengan tujuan memastikan bahwa data yang digunakan memiliki derajat kepercayaan dan tingkat signifikansi yang sesuai dengan asumsi yang digunakan pada penelitian ini yaitu derajat kepercayaan $95 \%$ dan tingkat signifikansi $5 \%$.

Selain pengujian kecukupan dan keseragaman data, sebelum dilakukan penghi-tungan waktu standar, diperlukan penentuan kelong- garan (allowance) yang dibutuhkan operator saat bekerja. Pada saat pelaksanaan eksperimen, operator tidak mampu bekerja secara terus menerus sepanjang hari tanpa adanya interupsi. Operator perlu menghentikan kerja dan membutuhkan waktu khusus untuk kebutuhan pribadi (personal need), istirahat melepas lelah (fatique need) dan alasan lain di luar kontrolnya (unavoidable delay), misalnya karena benang yang putus. Pada penelitian ini ditetapkan total waktu kelonggaran yang dibutuhkan oleh operator adalah sebesar $5 \%$ dari waktu total, yang terdiri atas $1,5 \%$ kelonggaran untuk kebutuhan pribadi, 1,5\% untuk istirahat melepas lelah diluar istirahat untuk makan, dan $2 \%$ untuk kelonggaran di luar kontrol. Penetapan kelonggaran ini didasarkan pada pertimbangan kualitatif peneliti setelah melakukan pengamatan terhadap kelonggaran yang dibutuhkan oleh operator saat melakukan eksperimen dan juga mempertimbangkan besarnya kelonggaran standar berdasar faktor-faktor yang berpengaruh.

Aspek terakhir yang perlu dipertimbangkan sebelum menghitung waktu standar adalah menentukan performance rating dari operator. Berdasar hasil pengamatan terhadap pelaksanaan eksperimen, dan juga membandingkan performansi operator terhadap performansi populasi keseluruhan (mahasiswa Tata Busana yang telah mengambil mata kuliah teknik pembuatan busana Industri), maka pada penelitian ini digunakan performance rating atau speed rating sebesar 1,00 atau $100 \%$. Hal ini ditetapkan dengan pertimbangan bahwa kecepatan kerja dan keterampilan pembuatan $t$-shirt yang dimiliki oleh operator mewakili kecepatan kerja dan keterampilan pembuatan $t$-shirt dari rata-rata mahasiswa Tata Busana dan juga berdasar penilaian kualitatif peneliti terhadap kecepatan kerja dan keterampilan operator berdasar tabel penilaian performance rating menurut Westing-house.

Tahap akhir penelitian ini adalah menghitung waktu normal dan waktu standar operator untuk menyelesaikan satu $t$-shirt anak. Waktu normal suatu elemen operasi kerja menunjukkan waktu yang dibutuhkan oleh ratarata operator untuk menyelesaikan pekerjaan 
dengan tempo kerja yang normal. Waktu normal pada tiap tahapan proses pembuatan $t$-shirt anak didapatkan dengan mengalikan waktu pengamatan dengan performance rating yang telah ditetapkan. Pada penelitian ini digunakan performance rating $=1,00$, sehingga waktu normal yang didapat sama besarnya dengan waktu normal. Waktu standar penyelesaian suatu pekerjaan dapat dihitung dari waktu normal yang telah ditambahkan dengan kelonggaran yang diberikan untuk menyelesaikan pekerjaan tersebut. Penelitian ini menggunakan kelonggaran sebesar $5 \%$.

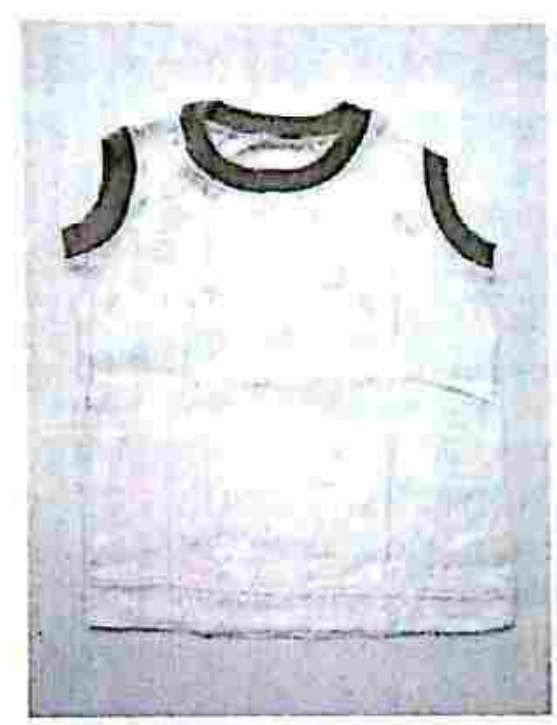

\section{Tahapan Pembuatan t-shirt Anak}

Tahapan pembuatan $t$-shirt anak yang dilakukan pada penelitian ini dapat dijelaskan sebagai berikut:

Tahapan yang pertama adalah membuat pola, yang diawali dengan pembuatan desain dan penentuan ukuran yang akan digunakan pada $t-$ shirt anak yang akan dibuat. Setelah itu dilanjutkan dengan pembuatan pola sesuai ukuran yang digunakan. Bentuk t-shirt anak yang digunakan pada penelitian ini, seperti terlihat pada Gambar 1.

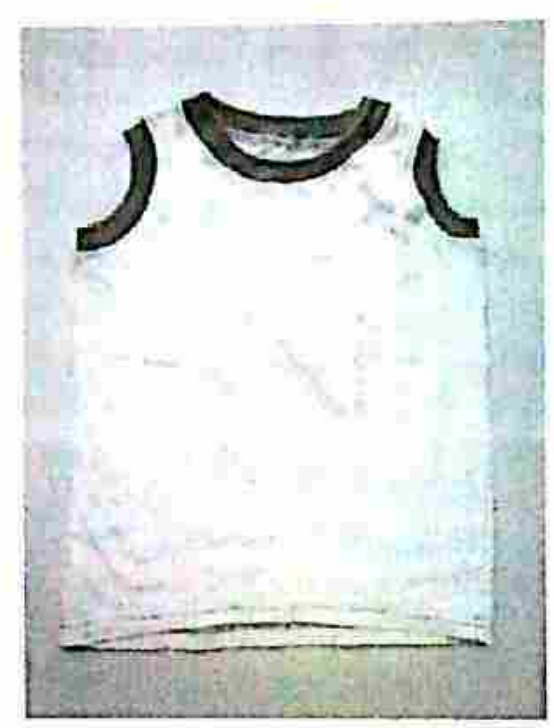

\section{Gambar 1. Bentuk t-shirt Anak}

Tahapan yang kedua adalah tahap menggunting. Proses memotong (cutting) t-shirt anak, secara garis besar terdiri atas lima pekerjaan 1) Spreading ialah proses membentangkan kain yang akan dipotong pada meja potong. Jumlah lipatan kain yang dibentangkan tergantung pada kapasitas mesin yang digunakan. Pada penelitian ini, karena keterbatasan alat pemotong yang tersedia, yaitu hanya berupa gunting biasa, maka jumlah kain yang dapat dipotong dalam satu kali pengguntingan hanya rangkap 3. Panjang dan lebar kain yang dibentangkan pada meja spreading ditata sesuai dengan masing-masing marker. Marker yang memuat gambar pola yang sudah dilengkapi dengan sisa jahitan (kampuh) diletakkan di atas bentang kain tersebut. Agar lembaran-lembaran kain tidak bergeser ketika ditumpuk, pada sudutsudut lembaran kain ditusuk dengan jarum. Bentangan kain siap dipotong 2) Cutting ialah kegiatan memotong bagian demi bagian pola yang tertuang dalam masing-masing marker. Selain melakukan potongan kain sesuai pola, juga dilakukan pemotongan kain rip yang digunakan pada leher dan lengan. Kain rip dipotong menggunakan mesin pemotong rip dengan lebar $12 \mathrm{~cm}$. Kemudian hasil pemotongan ini, dipotong lagi dengan panjang 
$33 \mathrm{~cm}$ untuk digunakan pada leher dan $16 \mathrm{~cm}$ untuk digunakan pada lengan. Setelah selesai dipotong, potongan kain dan potongan rip siap di-bundling 3) Bundling ialah proses pengelompokkan setiap bagian potongan menjadi suatu set pakaian. Tujuan bundling ialah menghindari adanya potongan kain yang tercecer, dan juga untuk memudahkan pemberian tanda sesuai dengan marker 4) Numbering : penomoran ikatan ukuran dalam satu bundling. Setiap satu bundling diberi nomor sesuai urutan lembaran nomor ukuran standarnya. Pada penelitian ini, karena hanya dibuat satu ukuran saja, maka numbering yang dilakukan hanya untuk memberikan tanda bagian muka dan bagian belakang 5) Panel Inspection ialah tahapan untuk memeriksa setiap lembar potongan kain dalam satu bundling agar tidak terdapat cacat kain dalam potonganpotongan kain yang akan dijahit.

Tahapan yang ketiga adalah tahap menjahit. Mesin jahit yang digunakan pada pembuatan $t$ shirt anak ini adalah mesin jahit yang umum digunakan pada usaha pembuatan busana berskala industri, sehingga mesin-mesin yang digunakan memiliki kecepatan yang cukup tinggi. Mesin-mesin yang digunakan antara lain : mesin jahit lurus, mesin obras benang 4 , dan mesin overdeck. Tahapan dalam menjahit $t$-shirt anak ini adalah menyambung bahu yaitu menyambung antara potongan bagian depan dan potongan bagian belakang, menyambung kedua sisi kiri dan kanan, menyambung rip untuk leher, menyambung rip untuk lengan, memasang rip pada leher, memasang rip pada lengan, kelim bagian bawah $t$-shirt, menindas tepi rip pada leher, dan menindas tepi rip pada lengan.

Tahapan yang keempat adalah tahap penyelesaian (finishing). Tahap ini merupakan tahapan akhir pada proses pembuatan $t$-shirt anak. Pada tahapan ini akan dilakukan proses penyempurnaan hasil jahitan yang berupa: 1) pembersihan sisa benang (trimming), proses untuk membersihkan sisa-sisa benang yang masih menempel pada hasil jahit ( $t$-shirt anak yang telah jadi); 2) pemeriksaan ukuran (size sorting) dimana ukuran $t$-shirt anak yang perlu diukur adalah lebar badan, panjang l-shirl, dan lebar punggung atas; 3) perbaikan (repairing) bila ada, merupakan tindakan perbaikan bila ditemukan ketidaksesuaian pada proses menjahit; 4) penyeterikaan (ironing); 5) pengelompokkan ukuran dan type (assorting size) yaitu mengelompokkan hasil jahitan sesuai dengan warna $t$-shirl yang dibuat. Dalam penelitian ini ada 2 buah warna yang dibuat, yaitu merah dan putih.

\section{Uji Kecukupan Data}

Jumlah observasi yang seharusnya dilakukan $\left(\mathrm{N}^{\prime}\right)$ dapat dihitung setelah tingkat kepercayaan dan tingkat keyakinan dalam pengukuran telah diketahui. Pada penelitian ini, menggunakan derajat kepercayaan $95 \%$ dan tingkat signifikansi $5 \%$, maka :

$$
\mathrm{N}^{1}=\left[\frac{40 \sqrt{N \sum X i^{2}-\sum(X i)}}{\sum X i}\right]^{2}
$$

(Wignjosoebroto, 2008). Jumlah yang diperoleh dari hasil perhitungan $\mathrm{N}^{\prime}$ merupakan jumlah data minimum yang harus dipenuhi agar hasil penelitian memenuhi derajat kepercayaan dan tingkat signifikansi yang diinginkan.

\section{Uji Keseragaman Data}

Derajat kepercayaan (confidence level) dan tingkat ketelitian (significant level) menggambarkan tingkat kepastian yang diinginkan dalam suatu penelitian setelah memutuskan tidak akan melakukan pengukuran terlalu banyak. Penelitian ini memakai $95 \%$ convidence level dan $5 \%$ degree of accuracy, hal ini berarti bahwa sekurang-kurangnya 95 dari 100 harga rata-rata dari waktu yang di catat akan memiliki penyimpangan tidak lebih dari $5 \%$. Hal ini dilakukan dengan pertimbangan bahwa penggunaan derajat kepercayaan $95 \%$ dan tingkat ketelitian $5 \%$ sudah cukup menjamin keakuratan data yang diperoleh dan juga dapat meminimasi jumlah data yang dibutuhkan tanpa mengurangi ketepatan pencapaian tujuan 
penelitian yang diinginkan. Semakin tinggi derajat kepercayaan dan semakin rendah tingkat signifikansi yang diinginkan, maka pengukuran yang diperlukan harus semakin banyak (Sutalaksana, 1979).

Akibat dari penggunaan derajat kepercayaan $95 \%$ dan tingkat ketelitian $5 \%$, maka untuk menentukan batas kontrolnya :

$$
\bar{X} \pm 3 \sigma \text {. }
$$

Di mana $\bar{X}$ adalah rata-rata hasil pengamatan dan $\sigma$ adalah standar deviasi hasil pengamatan. $\sigma$ dapat diukur dengan menggunakan persamaan

$$
\sigma=\sqrt{\frac{\sum(X i-\bar{X})^{2}}{N-1}} .
$$

Di mana $\mathrm{Xi}$ adalah hasil pengukuran data ke-i, dan $\mathrm{N}$ adalah jumlah data yang diamati

\section{HASIL DAN PEMBAHASAN}

Penghitungan waktu standar pembuatan $t$-shirt anak diukur berdasarkan keseluruhan waktu yang dibutuhkan untuk membuat satu potong $t$-shirt anak mulai dari pembuatan pola, menggunting, menjahit sampai dengan penyelesaian. Namun, karena tahapan proses yang diulang-ulang pada setiap pembuatan t-shirt anak hanya proses menjahit, maka penghitungan waktu standar dalam penelitian ini adalah waktu stanar dalam menjahit satu potong kain. Sedangkan proses lainnya yaitu membuat pola, menggunting dan penyelesaian, tetap diukur namun tidak diolah seperti halnya data waktu menjahit karena sifatnya hanya dilakukan satu kali oleh setiap objek penelitian (mahasiswa).

Hasil uji kecukupan data yang diperoleh ditunjukkan pada Tabel 1. Hasil uji kecukupan data dengan menggunakan derajat kepercayaan $95 \%$ dan tingkat signifikansi $5 \%$, seperti ditunjukkan pada Tabel 1. menunjukkan bahwa jumlah pengamatan yang dilakukan pada setiap tahapan proses (membuat pola, menggunting, menjahit, dan penyelesaian) sudah melebihi jumlah data minimum yang dibutuhkan untuk menjamin validitas hasil penghitungan ( $\mathrm{N}>\mathrm{N}^{\prime}$ ).

\begin{tabular}{|c|c|c|c|}
\hline \multirow{2}{*}{ No. } & \multirow{2}{*}{ Nama Proses } & \multicolumn{2}{|c|}{ Kecukupan Data } \\
\hline & & Jml Data Minimum $\left(\mathrm{N}^{\prime}\right)$ & Jnil Pengamatan (N) \\
\hline 1. & Membuat Pola & 8,54 & 10 \\
\hline \multirow[t]{6}{*}{2.} & Menggunting & & \\
\hline & - Spreading & 8,44 & io \\
\hline & - Cutting & 8,99 & 10 \\
\hline & - Bundling & 6,45 & 10 \\
\hline & - Numbering & 8,38 & 10 \\
\hline & - Inspection & 9,04 & 10 \\
\hline \multirow[t]{4}{*}{3.} & Menjahit & & \\
\hline & - Menyambung bahu & 14,42 & 30 \\
\hline & - Menyambung sisi & 7,04 & 30 \\
\hline & - Menyambung rip leher & 27,06 & 30 \\
\hline \multirow[t]{6}{*}{ ? } & - Menyambung rip lengan & 14,53 & 30 \\
\hline & - Memasang rip leher & 6,95 & 30 \\
\hline & - Memasang rip lengan & 3,36 & 30 \\
\hline & - Kelim bagian bawah t-shirt & 2,61 & 30 \\
\hline & - Tindas tepi rip leher & 5,04 & 30 \\
\hline & - Tindas tepi rip lengan & 5,70 & $\begin{array}{l}30 \\
30\end{array}$ \\
\hline \multirow[t]{4}{*}{4.} & Penyelesaian & & \\
\hline & - Trimming & & \\
\hline & - Pemeriksaan ukuran & 2,03 & 30 \\
\hline & - Penyetrikaan & 4,18 & 30 \\
\hline & & 4,33 & 30 \\
\hline
\end{tabular}

Tabel 1. Hasil Uji Kecukupan Data 
Hasil uji keseragaman data yang diperoleh ditunjukkan pada Tabel 2. Mengacu batas kontrol bawah (BKA) dan batas kontrol bawah (BKB) yang didapatkan dari hasil uji keseragaman data, seperti ditunjukkan pada Tabel 2, diketahui bahwa data hasil pengamatan pada setiap tahapan proses (membuat pola, menggunting, menjahit, dan penyelesaian) berada diantara batas kontrol atas dan batas kontrol bawah. Oleh sebab itu, data hasil pengamatan dapat disimpulkan seragam dan valid untuk digunakan dalam penghitungan waktu standar dan waktu normal pembuatan $t$ shirt.

Tabel 2. Hasil Uji Keseragaman Data

\begin{tabular}{|c|c|c|c|}
\hline \multirow[t]{2}{*}{ No. } & \multirow[t]{2}{*}{ Nama Proses } & \multicolumn{2}{|c|}{ Keseragaman data } \\
\hline & & Batas Kontrol Bawah ([3KI3) & Batas Kontrol Atas (BKA) \\
\hline 1. & Membuat Pola & 98,44 & 157,563 \\
\hline \multirow[t]{6}{*}{2.} & Menggunting & & \\
\hline & - Spreading & 30.66 & 48,94 \\
\hline & - Cutting & 19,84 & 31.16 \\
\hline & - Bundling & 2,46 & 3,69 \\
\hline & - Numbering & 1.03 & 1.65 \\
\hline & - Inspection & 1,70 & 2,76 \\
\hline \multirow[t]{11}{*}{3.} & Menjahit & & \\
\hline & Menyambung bahu & 81,18 & 125,62 \\
\hline & - Menyambung sisi & 135,51 & 171,42 \\
\hline & - Menyambung rip leher & 9,95 & 15,32 \\
\hline & - Menyambung rip lengan & 26,59 & 31,68 \\
\hline & - Memasang rip leher & 83,47 & 112,33 \\
\hline & - Memasang rip lengan & 153,19 & 181,48 \\
\hline & - Kelim bagian bawah t-shirt & 177.38 & 218,29 \\
\hline & - Tindas tepi rip leher & & \\
\hline & - Tindas tepi rip lengan & 75,25 & 94,62 \\
\hline & & 82,74 & 103,39 \\
\hline \multirow[t]{4}{*}{4.} & Penyelesaian & & \\
\hline & - Trimming & 68,26 & 81.08 \\
\hline & - Pemeriksaan ukuran & 161,09 & 203,78 \\
\hline & - Penyetrikaan & 196,53 & 258.34 \\
\hline
\end{tabular}

Secara umum, sesuai dengan uraian tahapan proses dan penghitungan waktu standar pada bagian metode, maka peta proses pembuatan 3 unit $t$-shirt anak dapat digambarkan menggunakan peta proses operasi seperti ditunjukkan pada Gambar 2. 


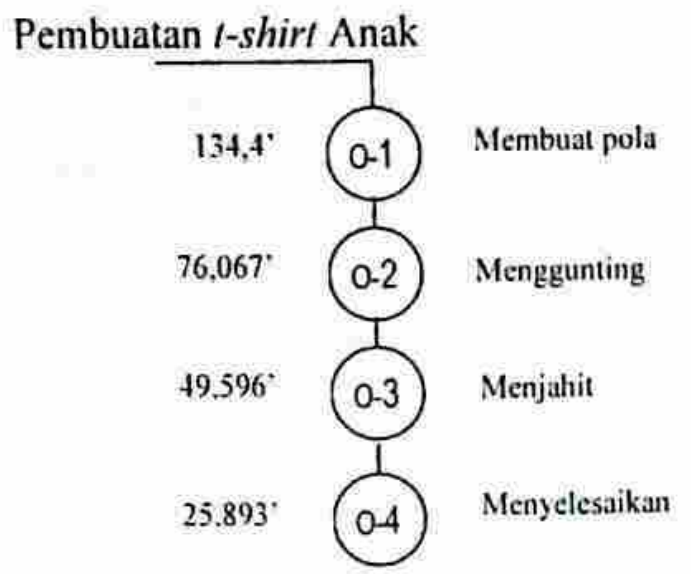

Gambar 2. Peta Proses Pembuatan t-shirt Anak

Sedangkan peta proses pada setiap tahapan, secara detail dapat ditunjukkan pada Gambar 3, Gambar 4, Gambar 5, dan Gambar 6.

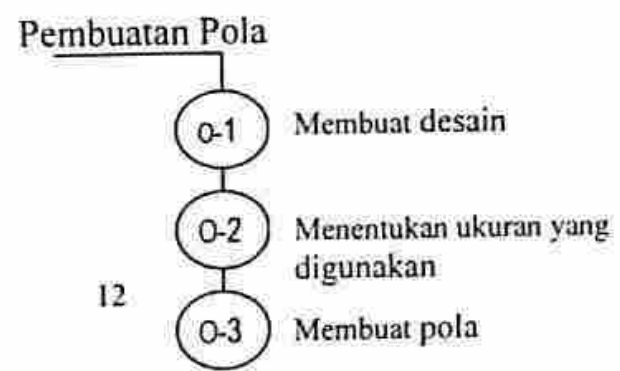

Gambar 3. Peta Proses Pembuatan Pola

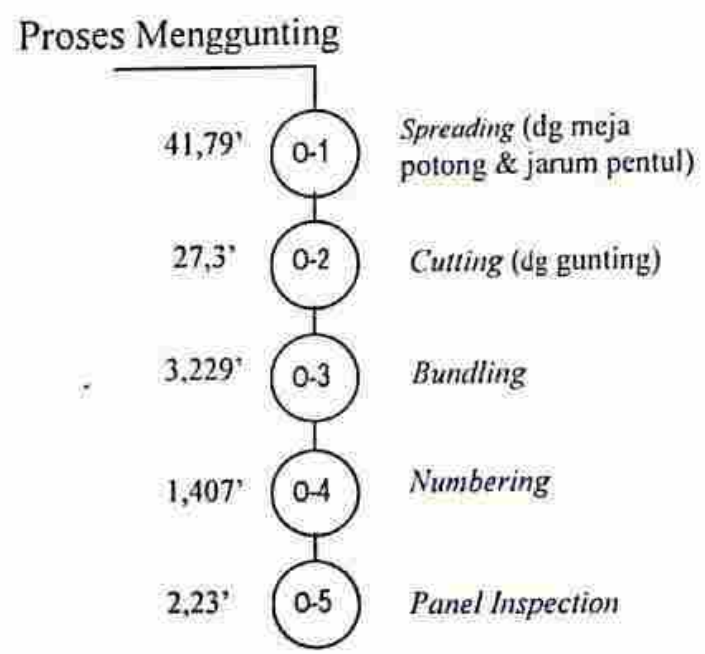

Gambar 4. Peta Proses Menggunting

\section{Proses Menjahit}

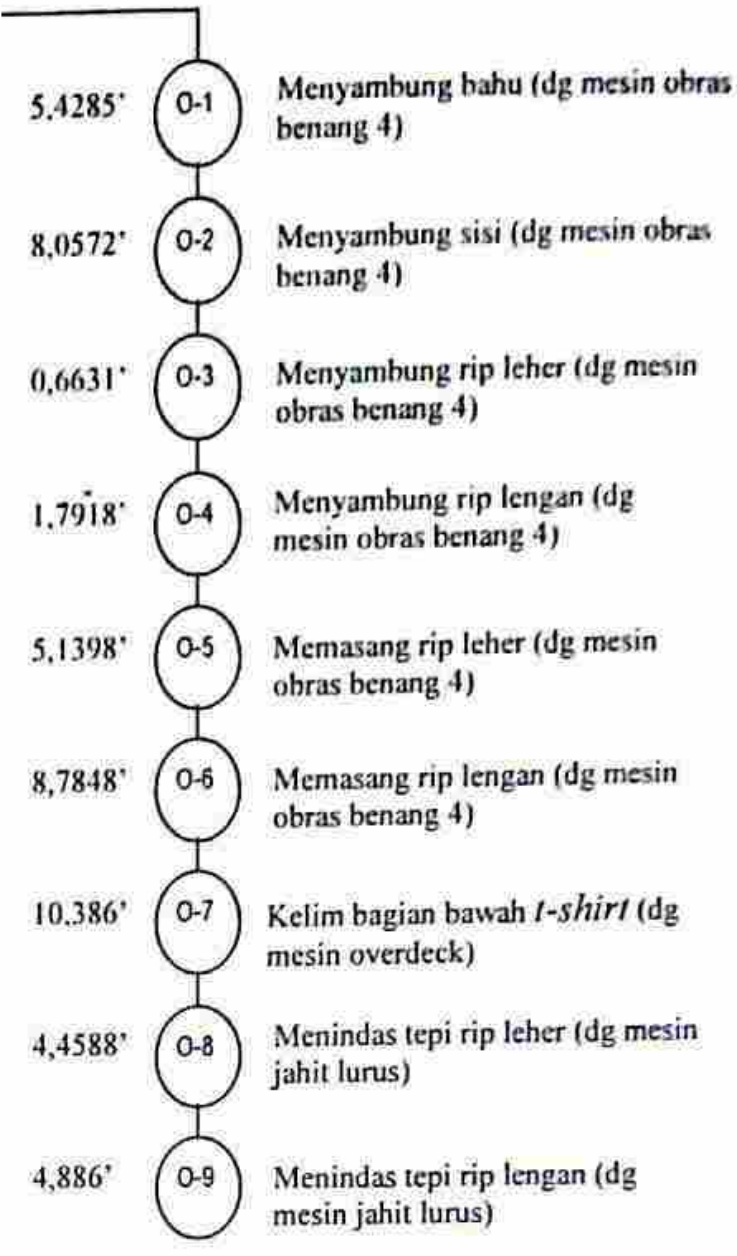

\section{Gambar 5. Peta Proses Menjahit}

Proses Penyelesaian

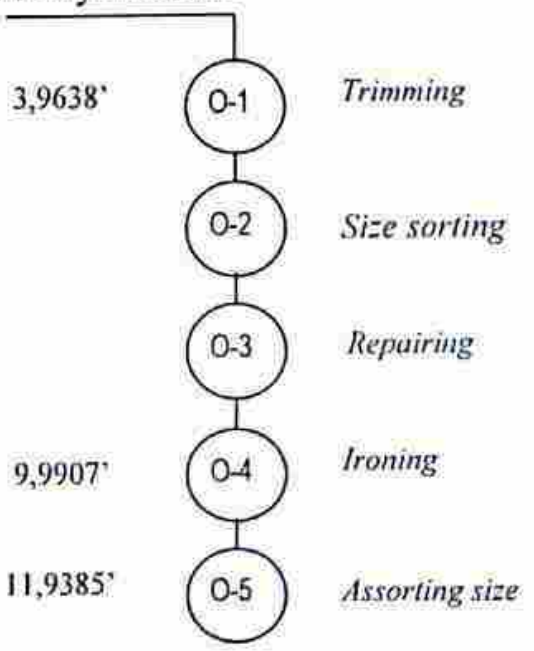


Hasil penghitungan waktu normal dan waktu standar pembuatan $t$-shirt berdasar data hasil pengamatan dan menggunakan allowance 5\% serta performance rating $100 \%$ ditunjukkan pada Tabel 3.

\section{Tabel 3. Hasil Perhitungan Waktu Normal dan Waktu Standar}

\begin{tabular}{|c|c|c|c|}
\hline No. & Nama Proses & Waktu Normal & Waktu Standar \\
\hline I. & Membuat Pola & 128 menit/pola & 134,4 menit-pola \\
\hline 2. & $\begin{aligned} & \text { Menggunting } \\
& \text { - } \text { Spreading } \\
&- \text { Cutting } \\
&- \text { Bundling } \\
&- \text { Numbering } \\
&- \text { Inspection } \\
&\end{aligned}$ & 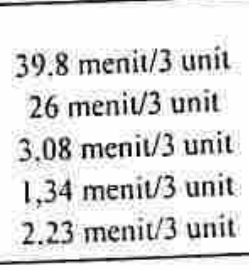 & $\begin{array}{l}41,79 \text { menit/3 unit } \\
27,3 \text { menit } / 3 \text { unit } \\
3,23 \text { meniv } / 3 \text { unit } \\
1,41 \text { menit } / 3 \text { unit } \\
2,23 \text { menit/3 unit }\end{array}$ \\
\hline 3. & $\begin{array}{l}\text { Menjahit } \\
\text { - Menyambung bahu } \\
\text { - Menyambung sisi } \\
\text { - Menyambung rip leher } \\
\text { - Menyambung rip lengan } \\
\text { - Memasang rip leher } \\
\text { - Memasang rip lengan } \\
\text { - Kelim bagian bawah } \text { t-shirt } \\
\text { - Tindas tepi rip leher } \\
\text { - Tindas tepi rip lengan }\end{array}$ & $\begin{array}{c}103,4 \text { detik/unit } \\
153,47 \text { detik/unit } \\
12.63 \text { detik/unit } \\
34,13 \text { detik/unit } \\
97,9 \text { detik/unit } \\
167.33 \text { detik/unit } \\
197.83 \text { detik/unit } \\
84,93 \text { detik/unit } \\
93.067 / \text { unit }\end{array}$ & $\begin{array}{c}108,57 \text { detik/unit } \\
161,14 \text { detik/unit } \\
13,26 \text { detik/unit } \\
25,84 \text { detik/unit } \\
102,80 \text { detik/unit } \\
175,70 \text { detik/unit } \\
207,72 \text { detik/unit } \\
89,18 \text { detik/unit } \\
97,72 \text { detik/unit }\end{array}$ \\
\hline 4. & $\begin{array}{l}\text { Penyelesaian } \\
\text { - Trimming } \\
\text { - Pemeriksaan ukuran } \\
\text { - Penyetrikaan } \\
\end{array}$ & $\begin{array}{l}75,5 \text { detik/unit } \\
190,3 \text { detik/unit } \\
227,4 \text { detik/unit }\end{array}$ & $\begin{array}{l}79,28 \text { detik/unit } \\
199,82 \text { detik/unit } \\
238,77 \text { detik/unit }\end{array}$ \\
\hline
\end{tabular}

Berdasarkan hasil pengamatan, diketahui bahwa kegiatan pembuatan pola hanya dilakukan satu kali selama proses produksi selama ukuran t-shirt anak yang dibuat adalah sama. Kegiatan cutting dapat dilakukan secara bersamaan untuk ketiga buah $t$-shirt, karena alat bantu yang tersedia untuk melakukan elemen-elemen cutting memungkinkan untuk melakukannya secara bersamaan. Kegiatan menjahit dan penyelesaian dilakukan secara repetitif pada setiap unit $t$-shirt anak yang dibuat.

Berdasar uraian di atas, maka dapat disimpulkan bahwa untuk memproduksi 3 unit 1 shirl, rata-rata mahasiswa membutuhkan waktu sebesar 285,9563 menit. Sehingga untuk output standar yang dapat dihasilkan oleh mahasiswa adalah 0,629467 unit/jam.
Hasil pengujian kecukupan data pada Tabel I menunjukkan bahwa pada setiap elemen proses pembuatan t-shirt anak, jumlah data yang seharusnya dilakukan/diamati $\left(\mathrm{N}^{1}\right)$ lebih besar dari jumlah data yang diamati $(\mathrm{N})$, sehingga dapat disimpulkan data mencukupi. Hal ini berarti bahwa jumlah data yang diamati mampu menjamin bahwa data yang akan diolah dalam penelitian ini mampu mencapai derajat kepercayaan dan tingkat ketelitian sesuai yang diinginkan/direncanakan.

Berdasar hasil pengujian keseragaman data pada Tabel 2, terlihat bahwa pada semua elemen proses pembuatan t-shirt anak, waktu proses yang diamati berada dalam batas kontrol, sehingga dapat disimpulkan bahwa data waktu proses yang diamati seragam. Hal ini menunjukkan bahwa operator yang diamati memiliki karakteristik yang serupa dan berasal dari populasi yang sama. 
Hasil perhitungan waktu normal dan waktu standar pada Tabel 3 menunjukkan bahwa tahapan proses yang memerlukan waktu paling lama adalah tahap membuat pola dan diikuti oleh tahap menggunting. Bila dianalisa lebih lanjut, dalam penbuatan busana industri, tahapantahapan ini hanya perlu dilakukan sekali dalam proses produksi suatu busana dengan model dan ukuran yang sama. Sehingga apabila jumlah produksi bertambat sebesar I unit, hanya akan menambah waktu produksi sebesar total waktu menjahit dan waktu penyelesaian per unit. Hal ini menunjukkan bahwa apabila model dan unit yang dihasilkan sama, semakin banyak jumlah produk yang dihasilkan maka total waktu produksi per unit yang dihasilkan semakin kecil. Inilah yang menjadi karakteristik unik dalam pembuatan busana industri.

Bila dianalisa lebih lanjut, hasil akhir penelitian berupa waktu standar mahasiswa untuk membuat t-shirt anak sebesar 0,6295 unit/jam atau setara dengan 3,1473 unit/5jam menunjukkan bahwa target produksi pada pelaksanaan kuliah teknik pembuatan busana industri dengan lama perkuliahan 6 js ( 1 js setara 50 menit), khususnya untuk pembuatan $t$-shirt anak yang selama ini dibebankan kepada mahasiswa sebanyak 3 unit per kelompok (1 kelompok terdiri atas 3 orang) masih dapat ditingkatkan lagi. Hal ini bertujuan agar mahasiswa dapat memacu dirinya terbiasa bekerja dengan kecepatan standar sehingga tidak perlu adaptasi terlalu lama bila harus menyesuaikan diri dengan kecepatan produksi di dunia busana industri.

Selain itu hal lain yang dapat mendorong peningkatan output produksi mahasiswa atau meningkatkan produktivitasnya adalah dengan menerapkan spesialisasi tahapan peñbuatan busana industri (sistem produksi ban berjalan). Penerapan spesialisasi ini akan dapat mengurangi waktu produksi yang dibutuhkan karena adanya kemampuan belajar alamiah yang terjadi bila seseorang melakukan pekerjaan yang berulangulang karena proses adaptasi, sehingga pada akhirnya dapat menghasilkan produk lebih banyak (Rastogi, 2010). Namun sisi buruk dari penerapan spesialisasi adalah mahasiswa menjadi terbiasa mengerjakan hanya satu tahapan proses saja.

\section{KESIMPULAN DAN SARAN}

Berdasar hasil penelitian yang diperoleh, dapat disimpulkan beberapa hal sebagai berikut: (1) Penyusunan peta proses operasi meliputi tahapan pengamatan, penentuan tahapan-tahapan proses, penentuan elemen-elemen kegiatan, dan penghitungan waktu standar. (2) Waktu standar yang diperlukan mahasiswa untuk membuat 3 unit t-shirt anak adalah 289,956 menit dan output standar sebesar 0,6295 unit/jam. (3) Jumlah output standar 3 kali lebih besar dibandingkan dengan target produksi pelaksanaan kuliah, sehingga mahasiswa memiliki potensi untuk ditingkatkan lebih besar lagi target produksinya.

Hasil penelitian ini terbatas hanya pada penyusunan peta proses operasi pembuatan $t$ shirt anak oleh mahasiswa sebagai objek penelitian. Oleh sebab itu, untuk penyempurnaan dan pengembangan pengajaran, maka dapat dilakukan benchmarking dengan pembuatan $t$ shirt anak di industri sehingga target perkuliahan yang dibebankan pada mahasiswa akan semakin mendekati dengan target di lapangan. Hal ini bertujuan agar tingkat produktivitas mahasiswa mendekati nilai tingkat produktivitas di dunia industri.

\section{DAFTAR RUJUKAN}

Dilworth, James B. 2005. Operation Management : design, planning, and control for manufacturing and services. 3rd Edition. Holt, Rinehart \& Winston of Canada Ltd.

Mundel, Marvin E. \& Danner, David L. 1994. Motion and Time Study: Improving Productivity. Englewood Cliffs, New York: Prentice Hall International.

Niebel, Benjamin W. 1993. Motion and Time Study. Homewood, IL : Richard D.Irwin.

Niebel, Benjamin W. \& Freivalds, Andris, 2003. Methods, Standards, and Work Design. 11 th edition. McGraw-Hill. 
Rastogi, MK. 2010. Production and Operation Management. New Delhi: University Science Press.

Sutalaksana, Iftikar. 1979. Teknik Tata Cara Kerja. Bandung: Departemen Teknik Industri ITB.

Wignjosoebroto, Sritomo. 2008. Ergonomi, Studi Gerak dan Waktu: Teknis Analisis Untuk Meningkatkan Produktivitas Kerja. Jakarta: Penerbit Guna Widya.

Whitmore, Dennis A. 1980. Work Measurement. London : Heinemenn-Institute of Management Services. 


\section{JURNAL}

TEKNOLOG INDUSTRT BOGA DAN BUSANA

Volume 9-Nomor 1 Maret 2013 :

ISSN $0216-7891$

IIA Agua llat Sil MI'a 